\title{
VIOLENCE AGAINST WOMEN IN RUSSIA AND BRAZIL: INTERNATIONAL AND DOMESTIC RESPONSES
}

\author{
GALINA NELAEVA, \\ University of Tyumen (Tyumen, Russia)
}

https://doi.org/10.21684/2412-2343-2021-8-4-76-102

The problem of domestic violence and violence against women, despite being an age-old phenomenon, came to the fore of public debate relatively late. It entered the agenda of intergovernmental organizations in the 1990s, but became the subject of international litigation only in the 2000s and 2010s. While this belated response of the international community can be associated with the inadequate conceptualization of the problem and insufficient data, it also has to do with the ongoing public/private dichotomy that became especially pronounced in the recent years when various conservative groups increasingly question the necessity of specific laws and policies aimed at eliminating this kind of crime. In this article, I briefly trace the developments concerning women's rights, and, particularly, domestic violence and violence against women in international law. Then, based on the analysis of international and regional court decisions, I try to see how and whether these decisions contributed to the domestic developments in the field of combatting this phenomenon in Russia and Brazil. It is also important to examine how COVID-19 pandemic impacted the narratives of violence and how the international community should respond to the challenge of protecting the most vulnerable members of the society in the conditions of health emergency.

Keywords: domestic violence; violence against women; Brazil; Russia; CEDAW; InterAmerican Commission of Human Rights; European Court of Human Rights.

Recommended citation: Galina Nelaeva, Violence Against Women in Russia and Brazil: International and Domestic Responses, 8(4) BRICS Law Journal 76-102 (2021). 


\section{Table of Contents}

\section{Introduction}

\section{History: Domestic Violence as a Human Rights Violation in International Law}

\section{Russian and Brazilian Submissions to the CEDAW Committee: States' Obligations and Women's Rights}

3. Regional Human Rights Protection Mechanisms and Domestic Violence

4. Domestic Responses to Violence against Women in Russia and Brazil

5. COVID-19 and Domestic Violence

\section{Conclusion}

\section{Introduction}

Violence committed against women and girls is an age-old phenomenon. Women are more likely to be subjected to violence on the part of their husbands or intimate partners than outsides. ${ }^{1}$ There are several concepts used by researchers and lawmakers to indicate abuse that might occur in a variety of contexts and relationships ranging from dating and cohabitation to an officially registered marriage, such as "intimate partner violence," "family violence," "domestic violence," "violence against women," "gender-based violence."² Rhona K.M. Smith emphasizes that,

Domestic violence is prevalent in all parts of the world, and is sometimes part of the ingrained culture. Latin America, Asia and the Pacific all produce evidence of cultures which condone (even passively) some domestic violence. One of the most significant problems with violence against women is the lack of public (official) awareness. Many women do not report domestic violence to the authorities and, even if they do, frequently they will not press charges. ${ }^{3}$

Biased attitudes of the law-enforcement officials, lack of training how to deal with such offenses, unfriendly and intrusive interrogation practices lead to the situation when domestic violence remains an invisible crime. In addition, frequently states do not have special statistics on such offenses (or such statistics is not easily accessible)

\footnotetext{
Ola W. Barnett et al., Family Violence Across the Lifespan: An Introduction 3 ( $3^{\text {rd }}$ ed. 2010).

2 It must be remarked that the Istanbul Convention, adopted by the Council of Europe in 2011, uses such terms as "violence against women and domestic violence." The latter term is meant to include not only women, but other vulnerable groups like children and the elderly. See the analysis of the Istanbul Convention in Sara De Vido, The Ratification of the Council of Europe Istanbul Convention by the EU: A Step Forward in the Protection of Women from Violence in the European System, 9(2) Eur. J. Leg. Stud. 69 (2017).
}

3 Rhona K.M. Smith, Texts and Materials on International Human Rights 543 ( $3^{\text {rd }}$ ed. 2013). 
making it difficult to trace the dynamics of this phenomenon, and complicates an overall picture of such crimes on the global level.

Although the problem is old, the interest to it is unwaning, not only among the media, but also in academic circles and among policy-makers and practitioners. This can be explained by several decisions that came out recently in international and regional courts, but also by the pandemic 2020, which brought to light such problems as victims' vulnerability in the conditions of self-isolation, the lack of appropriate services and the impossibility to physically separate the victims and the abusers.

Drawing on the feminist concept of intersectionality, ${ }_{1}^{4}$ would like to address two interrelated questions: how (and whether) international and regional human rights institutions understand the complex nature of violence experienced by women, as well as trace the impact of these decisions domestically on the examples of Brazil and Russia. I chose these two countries since they have been frequently brought about in literature as examples of an "anti-gender turn" currently unfolding globally. ${ }^{5}$ Finally, I would like to examine the omissions in the field of combatting domestic violence and violence against women that became apparent in 2020, in the conditions of the COVID-19 health crisis.

\section{History: Domestic Violence as a Human Rights Violation in International Law}

On the international level, the question of violence against women started to emerge on the agenda of international organizations relatively late, compared to discrimination, the initial frame used to discuss women's rights. Two mainstream human rights treaties, part of the International Bill of Rights, ICCPR (International Covenant on Civil and Political Rights) and ICESCR (International Covenant on Economic, Social and Cultural Rights) used the language of non-discrimination and equality, listing such grounds as "race, colour, sex, language, religion, political or other opinion, national or social origin, property, birth or other status."

4 The concept "intersectionality" was introduced in late 1980s by an American activist and a law professor, Kimberlé Crenshaw, to emphasize how oppression operates across multiple layers of an individual's identity. See, e.g., Kimberlé Crenshaw: What Is Intersectionality?, YouTube, 22 June 2018 (Feb. 10, 2021), available at https://www.youtube.com/watch/ViDtnfQ9FHc.

5 Kristina Stoeckl \& Kseniya Medvedeva, Double Bind at the UN: Western Actors, Russia, and the Traditionalist Agenda, 7(3) Glob. Const. 383 (2018); Back to the Past: Brazil's Backlash of Reproductive Justice in its Domestic and Foreign Policy, Center for Feminist Foreign Policy, 9 March 2020 (Feb. 10, 2021), available at https://centreforfeministforeignpolicy.org/journal/2020/3/9/back-to-the-past-brazils-backlash-ofreproductive-justice-in-its-domestic-and-foreign-policy; Elaine R. Brandão \& Cristiane da Silva Cabral, Sexual and Reproductive Rights Under Attack: The Advance of Political and Moral Conservatism in Brazil, 27(2) Sex. Reprod. Health Matters 76 (2019).

International Covenant on Civil and Political Rights, adopted and opened for signature, ratification and accession by General Assembly resolution 2200A (XXI) of 16 December 1966, entry into force 23 March 1976, Art. 26 (Feb. 10, 2021), available at https://www.ohchr.org/en/professionalinterest/ pages/ccpr.aspx; International Covenant on Economic, Social and Cultural Rights, adopted and opened 
The CEDAW Convention (Convention on the Elimination of Discrimination Against Women, 1979), in Article 1 also used the language of discrimination:

For the purposes of the present Convention, the term "discrimination against women" shall mean any distinction, exclusion or restriction made on the basis of sex which has the effect or purpose of impairing or nullifying the recognition, enjoyment or exercise by women, irrespective of their marital status, on a basis of equality of men and women, of human rights and fundamental freedoms in the political, economic, social, cultural, civil or any other field.

The CEDAW Committee issued several recommendations, however, that offered a more nuanced approach to discrimination and violence. According to Recommendation No. 25 related to temporary special measures,

certain groups of women, in addition to suffering discrimination directed against them as women, may also suffer from multiple forms of discrimination, based on additional grounds as race, ethnic or religious identity, disability, age, class, caste or other factors. ${ }^{7}$ [para. 12]

Recommendation No. 19 refers to gender-based violence and calls it "a form of discrimination that seriously inhibits women's ability to enjoy rights and freedoms on a basis of equality with men." Importantly, the Recommendation mentions that, "gender-based violence may breach specific provisions of the Convention, regardless of whether those provisions expressly mention violence." ${ }^{\prime 8}$ This conceptualization of violence and discrimination is important, since it has long been recognized by feminist scholars that "individuals can experience discrimination on the basis of multiple and intersecting identities." ${ }^{19}$ Discrimination never occurs alongside one particular trait only (gender, in this case): it is inexorably linked to questions of ethnic and racial belonging, social class, disability, and other aspects of identity.

The language of violence against women started to be explicitly used in international documents only in the 1990s. Controversy surrounding the question of

for signature, ratification and accession by General Assembly resolution 2200A (XXI) of 16 December 1966, entry into force 3 January 1976, Art. 2(2) (Feb. 10, 2021), available at https://www.ohchr.org/EN/ Professionallnterest/Pages/CESCR.aspx.

7 General recommendation No. 25: Article 4, paragraph 1, of the Convention (temporary special measures), $30^{\text {th }}$ Session (2004) (Feb. 10, 2021), available at https://tbinternet.ohchr.org/Treaties/ CEDAW/Shared\%20Documents/1_Global/INT_CEDAW_GEC_3733_E.pdf.

8 General recommendation No. 19:Violence against women, $11^{\text {th }}$ Session (1992) (Feb. 10, 2021), available at https://tbinternet.ohchr.org/Treaties/CEDAW/Shared\%20Documents/1_Global/INT_CEDAW_ GEC_3731_E.pdf.

9 Meghan Campbell, CEDAW and Women's Intersecting Identities: A Pioneering New Approach to Intersectional Discrimination, 11(2) Revista Direito GV 479, 480 (2015). 
violence mostly had to do with the dichotomy between public and private spheres of individuals'lives, when it was presumed that states were not supposed to intervene into the private domain. This was especially true in the classical understanding of public law in Western European countries and the United States where private matters were exempt from legal scrutiny. ${ }^{10} \mathrm{This}$ public/private dichotomy was criticized and questioned to stress that states were under an obligation to protect individuals from abuse in the private sphere. Namely, states should prevent, investigate and punish the occurrence of such acts." It was in 1993 that Declaration on the Elimination of Violence Against Women (Vienna Declaration) was adopted by the General Assembly (Res. 48/104, 20 December 1993). Article 1 of the Declaration defined "violence against women" in the following way:

Any act of gender-based violence that results in, or is likely to result in, physical, sexual or psychological harm or suffering to women, including threats of such acts, coercion or arbitrary deprivation of liberty, whether occurring in public or in private life.

The Declaration mentioned "physical, sexual and psychological violence" that occurs in the family, within the general community, in educational institutions and elsewhere (Art. 2). States should take measures to eliminate violence against women, as well as "condemn violence against women and should not invoke any custom, tradition or religious consideration to avoid their obligations with respect to its elimination" (Art. 4). In 1999, United Nations General Assembly declared November 25 an International Day for the Elimination of Violence Against Women. This day was chosen in the memory of women tortured and murdered by the Trujillo dictatorship in the Dominican Republic.'

Radhika Coomaraswamy, Special Rapporteur on Violence Against Women, presented her report in 1996, where she stressed that,

the role of State inaction in the perpetuation of the violence combined with the gender-specific nature of domestic violence require that domestic violence be classified and treated as a human rights concern rather than merely as a domestic criminal justice concern.

10 Sally F. Goldfarb, Violence Against Women and the Persistence of Privacy, 61(1) Ohio State L.J. 1 (2000) (Feb. 10, 2021), also available at https://kb.osu.edu/bitstream/handle/1811/70397/OSLJ_V61N1_0001. pdf? sequence $=1$.

11 Catherine Moore, Women and Domestic Violence: The Public/Private Dichotomy in International Law, 7(4) Int'I J. Hum. Rts. 93 (2010).

12 U.N. General Assembly, International Day for the Elimination of Violence Against Women, A/RES/54/134, 7 February 2000 (Feb. 10, 2021), available at https://undocs.org/en/A/RES/54/134. 
She also suggested the ways states could improve their domestic violence-related legislation, as well as take other measures necessary to address this problem. ${ }^{13}$

The Vienna World Conference of 1993 that led to the adoption of the Declaration, gave an impetus to the movement aimed at strengthening the CEDAW mechanism, which, by that time, was criticized for its ineffectiveness and even referred to as a "second-class instrument." ${ }^{\prime \prime}$ As a result, Optional Protocol to the Convention that envisaged the right of an individual petition was proposed at the Beijing World Conference on Women in 1995. The Protocol was adopted in 1999 (it entered into force in 2000). It gave the individuals the right to submit an individual communication in the conditions when the state party breached certain provisions of the Convention. The mechanism works in a similar way as other U.N. mechanisms: upon exhaustion of domestic remedies, an individual submits his/her application to the CEDAW Committee, which evaluates this submission and issues a decision on the merits and makes specific and general recommendations to the state. The Committee's views and recommendations are not legally binding, though the states are expected to give "due consideration" to them. It is also possible for the Committee to "designate one or more of its members to conduct an inquiry and to report urgently to the Committee. Where warranted and with the consent of the State Party, the inquiry may include a visit to its territory."15 According to Article 5 of the Optional Protocol, the Committee may adopt interim measures to prevent "irreparable damage" to a victim. An important point as well is that the Committee may adopt follow-up procedures in respect of communications, in accordance with Article 7(5). As of October 2020, there were 36 pending cases under the Optional Protocol. ${ }^{16}$ Even if, formally speaking, this mechanism is not a very strong one, views have been expressed that it can be

seen to provide women with a bridge to the longed-for human rights centre, the alternative to which is for women to be consigned to a peripheral existence marked by exclusion and persistent inequality. ${ }^{17}$

13 U.N. Economic and Social Council, Report of the Special Rapporteur on violence against women, its causes and consequences, Ms. Radhika Coomaraswamy, submitted in accordance with Commission on Human Rights resolution 1995/85, E/CN.4/1996/53, 5 February 1996 (Feb. 10, 2021), available at https://undocs.org/E/CN.4/1996/53.

14 Loveday Hodson, Women's Rights and the Periphery: CEDAW's Optional Protocol, 25(2) Eur. J. Int'I L. 561,562 (2014).

15 U.N. General Assembly, Optional Protocol to the Convention on the Elimination of All Forms of Discrimination Against Women, A/RES/54/4, 15 October 1999, Art. 8(2) (Feb. 10, 2021), available at https://www.ohchr.org/en/professionalinterest/pages/opcedaw.aspx.

16 Status of pending cases under the Optional Protocol to CEDAW, as of 27 October 2020, U.N. Human Rights Office (Feb. 10, 2021), available at https://www.ohchr.org/EN/HRBodies/CEDAW/Pages/ cedawindex.aspx.

17 Hodson 2014, at 565. 
The Committee also examines state-parties' periodic reports

on the legislative, judicial, administrative or other measures which they have adopted to give effect to the provisions of the present Convention and on the progress made in this respect. ${ }^{18}$

However, the first merits opinion of the CEDAW Committee related to domestic violence and violence against women came out more than ten years after the 1993 Vienna Declaration. The first case was Ms. A.T. v. Hungary (2005), when the Applicant complained that she was not able to obtain protection on the part of the state from her abusive ex-partner. Neither was she able to receive support from a women's refuge, since none of them offered essential support for her handicapped child. ${ }^{19}$ She also stressed that Hungarian law did not envisage the possibility of a restraining or protection order to keep the perpetrator away from her and her children. The Committee found a violation of Article 2(a), (b) and (e) (the obligation to adopt legislative and other measures to eliminate discrimination against women) and Article 5(a) (the need to adopt special measures necessary to eliminate prejudices) in conjunction with Article 16 (the need to adopt special measures to eliminate discrimination in family relations) of the CEDAW Convention. Other early cases that involved domestic violence and violence against women were brought against Austria, ${ }_{1}^{20}$ and touched upon the problem of insufficient implementation of domestic violence laws, as well as other structural problems. The Committee took a rather broad approach to the phenomenon of violence and recommended the states to take measures not only in these specific situations, but also in general, for instance, to adopt necessary laws, provide safe shelters to the victims, and educate state officials how to address such offenses.

\section{Russian and Brazilian Submissions to the CEDAW Committee: States' Obligations and Women's Rights}

Brazil is a party to major international and regional human rights conventions, including the CEDAW Convention, which it signed in 1981 and ratified in 1984.

18 Convention on the Elimination of All Forms of Discrimination Against Women, adopted and opened for signature, ratification and accession by General Assembly resolution 34/180 of 18 December 1979, entry into force 3 September 1981, Art. 18(1) (Feb. 10, 2021), available at https://www.ohchr.org/en/ professionalinterest/pages/cedaw.aspx.

19 Communication No. 2/2003, Ms. A.T. v. Hungary, CEDAW/C/36/D/2/2003, 26 January 2005 (Feb. 10, 2021), available at https://www.un.org/womenwatch/daw/cedaw/protocol/decisions-views/ CEDAW\%20Decision\%20on\%20AT\%20vs\%20Hungary\%20English.pdf.

20 Communication No. 5/2005, CEDAW/C/39/D/5/2005, 6 August 2007; Communication No. 6/2005, CEDAW/C/39/D/6/2005, 1 October 2007 (Feb. 10, 2021), available at https://www.ohchr.org/en/ hrbodies/cedaw/pages/jurisprudence.aspx. 
Optional Protocol to the Convention was signed in 2001 and ratified in 2002. Brazil is also a party to the Inter-American Convention on the Prevention, Punishment and Eradication of Violence Against Women (1995).

So far, there has been only one case examined by the CEDAW Committee against Brazil. ${ }^{21}$ Da Silva Pimentel Teixeira v. Brazil (2011) dealt with the victim's access to healthcare. ${ }^{22}$ The Applicant was a mother of a poor Afrodescendant woman, Alyne da Silva Pimentel Teixeira, who could not get proper medical treatment during childbirth, and died of health complications. The victim's mother alleged that there was a violation of her daughter's right to life and health under Articles 2 and 12 of the CEDAW Convention. While the question of violence was not raised in this case, it still showed the complexity of women's experiences, especially women "belonging to vulnerable and disadvantaged groups," and that

the duty to eliminate discrimination in access to health care includes the responsibility to take into account the manner in which societal factors, which can vary among women, determine health status. [para. 3.2]

Understanding women's rights as a broader term that encompasses social and economic rights is especially important in the Latin American context due the historical specificity of the feminist struggle in the region. As Katherine M. Marino remarks,

Feminismo americano demanded not only women's individual rights under the law - for the vote and for civil rights but also economic and social rights. ${ }^{23}$

In this particular case it was established that Brazil discriminated against the victim on the ground of "her status as a woman of African descent and her socioeconomic background" (para. 7.7).

Russia signed the CEDAW Convention in 1980 and ratified it in 1981. Optional Protocol to the Convention was signed in 2001, and ratified in 2004. Since 2004, there have been nine submissions registered by the Committee against Russia. ${ }^{24}$ Two submissions were declared inadmissible, violations were found in four of them. ${ }^{25} \mathrm{CEDAW}$ examined

21 Table of pending cases, U.N. Human Rights Office (Feb. 10, 2021), available at https://www.ohchr.org/ EN/HRBodies/CEDAW/Pages/cedawindex.aspx.

22 Communication No. 17/2008, CEDAW/11/C/49/D/17/2008, 27 September 2011 (Feb. 10, 2021), available at https://www.ohchr.org/Documents/HRBodies/CEDAW/Jurisprudence/CEDAW-C-49-D17-2008_en.pdf.

23 Katherine M. Marino, Feminism for the Americas: The Making of the International Human Rights Movement 4 (2019).

24 Statistical Survey on individual complaints, information as of 28 January 2020, U.N. Human Rights Office (Feb. 10, 2021), available at https://www.ohchr.org/Documents/HRBodies/CEDAW/StatisticalSurvey.xls.

25 S.T. v. Russia, CEDAW/C/72/D/65/2014; O.G. v. Russia, CEDAW/C/68/D/91/2015; X. and Y. v. Russia, CEDAW/C/73/D/100/2016; O.N. and D.P. v. Russia, CEDAW/C/75/D/119/2017. 
domestic violence in relation to Russia in the communication brought by S.T., a woman from Chechnya who complained of repeated physical and psychological abuse on the part of her ex-husband who even hit her with an axe, causing severe health injuries. ${ }^{26}$ It was emphasized in the submission that the victim was financially dependent on the abuser and could not afford to live separately (para. 2.4). It was also mentioned that she could not afford the necessary medical treatment to cure her injuries (para. 2.23), and her claims for compensation were dismissed by the court (para. 3.6). Neither could she go to a women's shelter because in her village there were none. She was blamed by the villagers for "provoking her husband," and her family members were stigmatized, even though they had also been subjected to abuse. Her husband, however, received a mild punishment because it was decided that he acted out of "temporary insanity" (para. 2.17). He was largely portrayed as a victim in the eyes of the court and the villagers. The Applicant claimed a violation of Article 2(c) and (d), read in conjunction with Article 1, and Article 5(a) of the CEDAW Convention since she was not able to get effective protection from the government. The case also involved difficult questions of religion and culture, and showed how different layers of identity (ethnic, social, gender) could intersect and become the basis of oppression.

The Committee in its recommendations stressed the state's obligation to properly investigate cases of gender-based violence, to provide victims with assistance and revise its legislation to bring it in conformity with international standards and the CEDAW Convention. Multiple systemic problems came to light as a result of these submissions, such as the lack of psychological rehabilitation for the victims, the lack of training for the police officers, and so on.

\section{Regional Human Rights Protection Mechanisms and Domestic Violence}

Regional human rights protection mechanisms have been instrumental in examining the problem of violence against women. The American Convention on Human Rights (1969) contains the right of an individual and group petition in cases of human rights violations (it was ratified by Brazil in 1992). The Inter-American Convention on the Prevention, Punishment, and Eradication of Violence Against Women (Convention of Belém do Pará) was passed in 1994 by the General Assembly of the Organization of American States (ratified by Brazil in 1995).

Violence against women has frequently become the subject of human rights litigation in the Latin American context. It covered such questions as rape, torture and sexual violence in armed conflicts, ${ }^{27}$ violence against indigenous women, ${ }^{28}$ the

26 Communication No. 65/2014, CEDAW/C/72/D/65/2014, 8 April 2019 (Feb. 10, 2021), available at https:// undocs.org/en/CEDAW/C/72/D/65/2014.

27 Caso Masacre Plan de Sánchez v. Guatemala, Reparaciones, 19 November 2004, Serie C No. 116 (Feb. 10, 2021), available at https://www.corteidh.or.cr/docs/casos/articulos/seriec_116_esp.pdf.

28 Caso Fernández Ortega y otros v. México, Excepción Preliminar, Fondo, Reparaciones y Costas, 30 August 2010, Serie C No. 215 (Feb. 10, 2021), available at https://www.corteidh.or.cr/CF/jurisprudencia2/ ficha_tecnica.cfm?nld_Ficha $=338$. 
states' duty to prevent, investigate and sanction violence against women, ${ }^{29}$ forced sterilization of women in hospitals. ${ }^{30}$ These developments, in part, are attributed to the activities of women's rights groups in the region, as well as to the activism of lawyers and female judges on the bench. ${ }^{31}$

In the Inter-American system of human rights protection (that includes the Commission and the Court) the question of domestic violence and violence against women was examined in the famous Maria da Penha case brought against Brazil in 2001..$^{32}$ The Commission relied on the American Declaration of the Rights and Duties of Man and the Convention of Belém Do Pará to establish whether Brazil was responsible for breaching these treaties (the latter treaty was applied for the first time in this case). The Applicant, Maria da Pehna Maia Fernandes, complained that her husband tried to murder her several times (which left her paraplegic since 1983 at the age of thirty-eight, and caused other serious bodily harm), and state authorities did nothing to protect her and punish her husband, even though she brought repeated complaints against him. He was arrested only in October 2002, nineteen years after the crime had been committed and the statute of limitations had almost expired. In 2007 he was released on probation. ${ }^{33}$ Given that the victim and the perpetrator were both middle-class educated people, this case demonstrated that domestic violence could not be attributed to certain individuals with anti-social behavior or a lack of education, but could happen in any social class, regardless of the educational, material or other factors.

The Commission established that,

The failure to prosecute and convict the perpetrator under these circumstances is an indication that the State condones the violence suffered by Maria da Penha, and this failure by the Brazilian courts to take action is exacerbating the direct consequences of the aggression by her ex-husband. [para. 55]

Caso Gelman v. Uruguay, Fondo y Reparaciones, 24 February 2011, Serie C No. 221 (Feb. 10, 2021), available at https://www.corteidh.or.cr/docs/casos/articulos/seriec_221_esp1.pdf.

30 Caso I.V. v. Bolivia, Excepciones Preliminares, Fondo, Reparaciones y Costas, 30 November 2016, Serie C No. 329 (Feb. 10, 2021), available at https://www.corteidh.or.cr/docs/casos/articulos/seriec_329_esp.pdf.

31 Mariana Prandini Assis, Violence Against Women as a Translocal Category in the Jurisprudence of the Inter-American Court of Human Rights, 8(2) Revista Direito e Práxis 1507 (2017) (Feb. 10, 2021), also available at https://www.scielo.br/scielo.php?script=sci_abstract\&pid=S2179-89662017000 201507\&lng=en\&nrm=iso.

32 Maria da Penha Maia Fernandes v. Brazil, Case 12.051, Report No. 54/01, OEA/Ser.L/V/II.111 Doc. 20 rev. at 704 (2000) (Feb. 10, 2021), available at http://www.cidh.org/annualrep/2000eng/Chapterlll/ Merits/Brazil12.051.htm.

33 Ana P. Martins Amaral \& Ellen C. Rocha Amorim, A Lei 11.340/2006 - Lei Maria da Penha - como fruto dos compromissos internacionais assumidos pelo Brasil e de sua condenação perante a Comissão Interamericana de Direitos Humanos, 29(2) Revista Justiça do Direito 179, 186 (2015). 
The Commission went on to stress that this situation was not an isolated occurrence, but

a general pattern of negligence and lack of effective action by the State in prosecuting and convicting aggressors ... this case involves not only failure to fulfill the obligation with respect to prosecute and convict, but also the obligation to prevent these degrading practices. That general and discriminatory judicial ineffectiveness also creates a climate that is conducive to domestic violence, since society sees no evidence of willingness by the State, as the representative of the society, to take effective action to sanction such acts. [para. 56]

The Commission found a violation of Articles 8 and 25 of the American Convention (right to a fair trial and judicial protection). The Commission also established that the Applicant was denied equal protection guaranteed by Article 24 of the American Convention. Articles II and XVIII of the American Declaration, Article 1.1 of the American Convention, and Article 7 of the Convention of Belém do Pará (a state's obligation to undertake policies to prevent, punish, and eradicate violence against women) were also breached by Brazil (para. 60.1).

Brazil's law enforcement and judicial systems came under intense scrutiny in this case. Even if violence against women was a widespread phenomenon, victims' complaints were not fully investigated and perpetrators were not prosecuted. Relying on various reports by NGOs and other organizations, the Commission stated that,

$70 \%$ of the criminal complaints pertaining to domestic violence are put on hold without any conclusion being reached. Only $2 \%$ of the criminal complaints for domestic violence against women lead to conviction of the aggressor. [para. 49]

On the European continent, there have been several treaties that address the question of domestic violence and violence against women. ${ }^{34}$ In the European Court of Human Rights (ECtHR) jurisprudence, the issue of domestic violence has been examined by the Court under various European Convention's provisions, including Article 2 (right to life), Article 3 (prohibition of torture and inhuman or degrading treatment), Article 6 (right to a fair trial), Article 8 (right to private and family life), Article 14 (prohibition of discrimination) and involved such complex issues as alleged risk of being subjected to domestic violence in case of deportation, insufficient investigation of domestic violence offenses, alleged failure by the state

34 Libor Klimek, Domestic Violence in European Legal Documents, 6(0) CBU Int'I Conf. Proc. 647 (2018) (Feb. 10, 2021), also available at https://ojs.journals.cz/index.php/CBUIC/article/view/1227/1769. 
institutions to provide women with adequate protection against perpetrators, states' obligation to protect physical and psychological integrity of individuals, confidentiality of correspondence, cyberbullying, etc. ${ }^{35}$ It is firmly established in the Court's jurisprudence that states must exercise due diligence when trying to fulfill their obligations to combat domestic violence. ${ }^{36}$

The first case against Russia that involved domestic violence came out in July 2019 and immediately became the subject of unprecedented media scrutiny. The ECtHR decision coincided with ongoing public debates over the necessity to introduce a special bill to combat domestic violence, and showed how polarized the Russian society was on this matter. The Applicant, Valeria Volodina, a young woman from Ulyanovsk, frequently brought complaints against her partner since he constantly physically and verbally assaulted her, which led to a medically-induced abortion due to a possibility of a miscarriage. He also caused damage to her property, took her identity documents, posted her private photos on the Internet without her consent, put a tracking device in her bag and traced her movements, resorted to stalking and death threats. The state authorities, however, remained largely dismissive of her complaints and criminal charges were never properly pursued (they were either dropped or not brought at all). Fearing for her life, she had to change her name and flee her town. ${ }^{37}$

The Court pointed to the positive obligations of the states under Article 3, namely,

the obligation to establish and apply in practice an adequate legal framework affording protection against ill-treatment by private individuals; the obligation to take the reasonable measures that might have been expected in order to avert a real and immediate risk of ill-treatment of which the authorities knew or ought to have known, and the obligation to conduct an effective investigation when an arguable claim of ill-treatment has been raised. [para. 77]

The fact that the authorities did not pursue criminal investigation against the offender despite continuous complaints against him, and did not introduce any measures to protect the victim, led the Court to believe that there was a violation of Article 3 for the failure to investigate the ill-treatment of the Applicant (para. 101). It is important that the ECtHR continuously denied that domestic violence could be regarded as a "private matter" (para. 105).

35 ECtHR, Factsheet: Domestic Violence (July 2021) (Feb. 10, 2021), available at https://www.echr.coe. int/Documents/FS_Domestic_violence_ENG.pdf.

36 Lee Hasselbacher, State Obligations Regarding Domestic Violence: The European Court of Human Rights, Due Diligence, and International Legal Minimums of Protection, 8(2) Nw. J. Int'I Hum. Rts. 190 (2010) (Feb. 10, 2021), also available at http://scholarlycommons.law.northwestern.edu/njihr/vol8/iss2/3.

37 Volodina v. Russia, Application No. 41261/17, 9 July 2019. 
The Court also found that domestic violence in Russia disproportionately affected women and found a violation of Article 3 and Article 14 (taken in conjunction with Article 3). According to police data for the period 2015-2017,

women made up between $67 \%$ to $74 \%$ of all adult victims of registered crimes "committed within the family or household." The offence of battery, which is the most common form for prosecution of minor violence, appears to have targeted exclusively women and children, as the total number of those two categories of victims was equal to, or larger than, the total number of registered incidents. [para. 119]

Polshina v. Russia ${ }^{38}$ (16 June 2020) was the second case when the ECtHR examined domestic violence and found a violation of Article 3 in conjunction with Article 14 of the Convention because of police's failure to investigate complaints and the state's failure to provide legal protections for the victims of domestic violence. Svetlana Polshina from St. Petersburg complained of systematic physical and verbal assaults on the part of her husband, including death threats, as well as preventing her from having social contacts and even from seeing her son. The assaults were going on for more than two years, the perpetrator, however, was not punished. The injuries of the victim were deemed not serious enough to become the basis of prosecution. The Court noted that,

The continued failure to adopt legislation to combat domestic violence and the absence of any form of restraining orders clearly demonstrate that the Russian authorities were reluctant to acknowledge the seriousness and extent of the problem of domestic violence in Russia and its discriminatory effect on women. [para. 46]

The next submission, Tunikova, Petrakova, Gershman and Gracheva v. Russia was communicated on 28 June 2019. The most notoriously famous case was that of Margarita Gracheva, whose hands were chopped off by her husband. As a result of this brutal attack, she had to undergo very complex surgeries, including the one that enabled her to have a bionic right hand. ${ }^{39}$ When asked to respond to this submission, the Justice Ministry representatives were quoted as saying that,

As for the alleged violation of Article 14, the Government emphasize that yet the phenomenon of domestic violence is regrettably widespread

\footnotetext{
38 Polshina v. Russia, Application No. 65557/14, 16 June 2020.

39 Lucy Ash, Russian Domestic Violence: Women Fight Back, BBC News, 21 November 2019 (Feb. 10, 2021), available at https://www.bbc.com/news/election-2019-50493758.
} 
all around the world and do exist in Russia as well as in any other county, the scope of the problem of violence within family and household as well as the gravity and extend of its discriminatory effect on women in Russia is sufficiently exaggerated. ${ }^{40}$

This response caused much discontent among the victims' relatives who blamed the government for downplaying the seriousness of the problem. ${ }^{41}$ At the time of writing, the decision has not been made yet, but it is almost certain that the ECtHR will come to very similar conclusions as in its previous judgments.

\section{Domestic Responses to Violence Against Women in Russia and Brazil}

Decisions of international and regional human rights bodies received wide resonance domestically, in both Brazil and Russia. As Paula Spieler remarks, before 2001 , there was little interest in the topic of domestic violence in the Brazilian society, even if certain measures had already been introduced, i.e. opening of shelters, ${ }^{42}$ special police stations ("delegacias de mulheres," set up in 1985), as well as Supreme Court condemnation of "honor defense" in cases of wife-killing. ${ }^{43}$ There was no special law on domestic violence, and such pervasive problems as "honor killings" came to the attention of the media only in high-profile cases. And even if high-profile cases resulted in actual conviction, the perpetrators usually received very short sentences. ${ }^{44}$ However, after the Commission's report on Maria da Penha case, new initiatives started to emerge, accompanied by extensive media coverage, NGO activism and public discussions. Several conferences and seminars were held in Brazil to dwell

40 Russia's Justice Ministry says journalists distorted its argument that domestic violence claims in Russia are exaggerated. Fine, here's the full quote, Meduza, 19 November 2019 (Feb. 10, 2021), https:// meduza.io/en/feature/2019/11/19/russia-s-justice-ministry-says-journalists-distorted-its-argumentthat-domestic-violence-claims-in-russia-are-exaggerated-fine-here-s-the-full-quote.

41 Calls to probe Russian official over stance on domestic abuse, France 24, 21 November 2019 (Feb. 10, 2021), available at https://www.france24.com/en/20191122-calls-to-probe-russian-official-overstance-on-domestic-abuse.

42 As of 2014, there were 74 "safe houses" operating in Brazil. See Table IV.4. Latin America and the Caribbean: shelters and safe houses for women victims of violence in Economic Commission for Latin America and the Caribbean, Annual Report 2013-2014. Confronting violence against women in Latin America and the Caribbean (2014), at 60 (Feb. 10, 2021), available at https://www.cepal.org/en/ publications/gender-equality-observatory-latin-america-and-caribbean-annual-report-2013-2014.

43 Paula Spieler, The Maria da Penha Case and the Inter-American Commission on Human Rights: Contributions to the Debate on Domestic Violence Against Women in Brazil, 18(1) Indiana J. Glob. Leg. Stud. 121 (2011).

44 Jodie G. Roure, Domestic Violence in Brazil: Examining Obstacles and Approaches to Promote Legislative Reform, 41(1) Colum. Hum. Rts. L. Rev. 67, 73-74 (2009) (Feb. 10, 2021), also available at https://www. corteidh.or.cr/tablas/r23765.pdf. 
on the possible governmental responses to the problem, and the year 2004 was declared the "Year of the Woman." In 2005, "the National Campaign on Violence Against Women: Tolerance Zero" was initiated. ${ }^{45}$

Several amendments were made to the country's civil and criminal codes, which sought to promote equality between women and men in marriage in matters of property, and to remove certain moralistic categories such as an "honest woman" or a "virgin woman." Significant sums of money were allocated to develop programs within National Pact to Combat Violence Against Women (Pacto Nacional pelo Enfrentamento à Violência contra a Mulher). ${ }^{46}$

More importantly, however, in 2006 Brazil introduced the so-called Maria da Penha Law (Law No. 1134/2006), which incorporated a gender perspective into the federal criminal law. The legislative act envisaged the establishment of special courts and stricter sentences for perpetrators, as well as other instruments in cities of more than 60,000 inhabitants (for example, police stations and shelters for women). According to the National Council of Justice in Brazil, as of 2011, the results were positive: there were more than 331,000 prosecutions and 110,000 final judgments, and nearly two million calls to the Service Center for Women. ${ }^{47}$ In 2018 the law was amended to include the obligation imposed on the perpetrator to reimburse the Unified Health System for any expenses incurred with victims of domestic violence. According to Bill No. 5001/16, the aggressor might also face an obligation to attend rehabilitation and re-education programs. ${ }^{48}$

Law No. 13.104/2015 ("Lei do Feminicídio") was an amendment to the country's criminal code passed in 2015 in order to classify feminicide (i.e. gender-related killing) as a circumstance equivalent to murder. ${ }^{49}$

Researchers also emphasized that Brazil became more active internationally promoting women's rights approach in its foreign policy. Thus, in March 2017, Brazil

45 See also Table IV.3. Latin America and the Caribbean: campaigns against violence against women in Economic Commission for Latin America and the Caribbean, Annual Report 2013-2014, supra note 42, at 59,60 .

46 Spieler 2011, at 136-137. For more details, see Secretaria de Políticas para as Mulheres da Presidência da República, Pacto Nacional pelo Enfrentamento à Violência contra as Mulheres (2011) (Feb. 10, 2021), available at https://www12.senado.leg.br/institucional/omv/entenda-a-violencia/pdfs/pactonacional-pelo-enfrentamento-a-violencia-contra-as-mulheres.

47 Maria da Penha Law: A Name that Changed Society, U.N. Women, 30 August 2011, available at https:// www.unwomen.org/en/news/stories/2011/8/maria-da-penha-law-a-name-that-changed-society.

48 CEPAL, Comprehensive National-Level Review Report on the Implementation of the Beijing Declaration and Platform for Action - Brazil (May 2019) (Feb. 10, 2021), available at https://www.cepal.org/sites/ default/files/informe_beijing25_brasil.pdf.

49 Sebastián Essayag, From Commitment to Action: Policies to End Violence Against Women in Latin America and the Caribbean: Regional Analysis Document, U.N. Development Programme \& U.N. Women (2017) (Feb. 10, 2021), available at https://reliefweb.int/sites/reliefweb.int/files/resources/UNDP-RBLACReportVCMEnglish.pdf. 
launched its National Action Plan on Women, Peace, and Security the country's commitment to the agenda laid out in the series of resolutions beginning with the U.N. Security Council Resolution 1325 (2000). ${ }^{50}$

Despite these initiatives, however, as the Inter-American Commission on Human Rights reported in 2019, four women were killed each day in Brazil and the state was not doing enough to prevent and prosecute femicide, even if the necessary law was in place. ${ }^{51}$ Human Rights Watch, in particular, pointed to the fact that,

As of 2018, only 8 percent of municipalities had established police stations specializing in violence against women and only about 2 percent operated women's shelters, both requirements of the law..$^{52}$

Brazil's President Jair Bolsonaro is criticized for cutting the funds for women's rights programs and for his openly anti-gender stance. ${ }^{53}$ Even if the implementation of the above-mentioned initiatives has been rather uneven and produced mixed results, ${ }^{54}$ still, with the adoption of the special law,"the spread of human rights norms appears to have been significant.".155

In Russia, the idea to adopt a special law to combat domestic violence emerged already in the 1990s. However,

over the past 10 years, this bill has been submitted to the State Duma for consideration more than 40 times, but has never passed the first of the three required readings. ${ }^{56}$

50 Mónica Salomón, Exploring Brazilian Foreign Policy Towards Women:Dimensions, Outcomes, Actors and Influences, 63(1) Revista Brasileira de Política Internacional 1 (2020) (Feb. 11, 2021), also available at https://www.scielo.br/scielo.php?script=sci_arttext\&pid=S0034-73292020000100204.

51 Brazil: four women killed every day in 2019, human rights body says, The Guardian, 4 February 2019 (Feb. 11, 2021), available at https://www.theguardian.com/world/2019/feb/04/brazil-women-killed2019-rate-alarming-iachr.

52 Submission to the Committee on the Elimination of All Forms of Discrimination Against Women (CEDAW) on Brazil, 79 $9^{\text {th }}$ CEDAW Pre-Session, Human Rights Watch, 21 October 2020 (Feb. 11, 2021), available at https://www.hrw.org/news/2020/10/21/submission-committee-elimination-all-formsdiscrimination-against-women-cedaw-0\#_ftn 1 .

53 Id. See also Katy Watson, 'Feminism is sexist': The women backing Brazil's Bolsonaro, BBC News, 23 October 2018 (Feb. 11, 2021), available at https://www.bbc.com/news/world-latin-america-45944164.

54 Essayag, supra note 49, at 73-78.

55 Marina Wilbraham, The Maria da Penha Law and the Media: Understanding the Adoption of Human Rights Norms on Domestic Violence in Brazil, BA Thesis, Columbia University (2019) (Feb. 11, 2021), available at https://academiccommons.columbia.edu/doi/10.7916/d8-5dxm-s088.

56 Olimpiada Usanova, Russia's "Traditional Values" and Domestic Violence, Kennan Cable No. 53 (June 2020) (Feb. 12, 2021), available at http://wilsoncenter.org/publication/kennan-cable-no-53-russiastraditional-values-and-domestic-violence. 
It was not until November 2019 that a new version of the draft law was introduced in the Federation Council, and because of Volodina v. Russia judgment became an object of heated debate in the public arena. The controversy surrounding the Bill showed how difficult it can be to achieve a societal consensus in such a sensitive area. If initially activists and human rights defenders took an active part in the process of drafting the law, at a later stage, when a modified version of the law was presented, they expressed their discontent and disappointment with the result. ${ }^{57}$

One of the most contentious issues in the proposed draft law has been the definition of "family and domestic violence," criticized by both liberal and conservative groups of the society. Namely, the discontent centered around the fact that this phenomenon was defined as

a deliberate act that causes or contains a threat of causing physical and (or) mental suffering and (or) property harm, which does not contain elements of an administrative offense or a criminal offense..$^{58}$

Activists questioned this conceptualization of violence, pointing that violence as such always contained elements of either an administrative or a criminal offense, and it was hard to imagine what situations the drafters had in mind when they suggested this definition. Practicing lawyers pointed to the uselessness of such a law for the victims due to this conceptual ambiguity. ${ }^{59}$

The question of a restraining/protection order has been at the center of a heated debate as well..$^{0}$ What should this order look like? Who should it be enforced by, and how? Will it really protect the victims? Wouldn't it be used by representatives of state institutions as a ground for taking children away from their parents? On the other hand, the lack of such a protective mechanism has been referred to in literature as

57 Vladislav Gorin, Negligible and largely useless: Why women's rights advocates in Russia have turned against the draft version of their law against domestic violence, Meduza, 2 December 2020 (Feb. 12, 2021), available at https://meduza.io/en/feature/2019/12/02/negligible-and-largely-useless.

58 Проект федерального закона «О профилактике семейно-бытового насилия в Российской Федерации» [Draft Federal Law“On the Prevention of Domestic Violence in the Russian Federation"] (Feb. 10, 2021), available at http://council.gov.ru/media/files/rDb1bpYASUAxolgmPXEfKLUlq7JAARUS.pdf.

59 «Ни одну потерпевшуюя не смогу защитить этим законом»: Адвокат Мари Давтян о законопроекте о профилактике семейно-бытового насилия // Коммерсантъ. 29 ноября 2019 г. ["I Will Not Be Able to Protect a Single Victim with This Law": Advocate Mary Davtian About the Draft Law on the Prevention of Domestic Violence, Kommersant, 29 November 2019] (Feb. 10, 2021), available at https:// www.kommersant.ru/doc/4178442.

60 Почему не нужен закон о профилактике домашнего насилия? Часть III (интервью с Людмилой Виноградовой (членом Общественной палаты Российской Федерации, судьей в почетной отставке)) // YouTube. 16 сентября 2019 г. [Why Is There No Need for a Law on the Prevention of Domestic Violence?" Part III (interview with Liudmila Vinogradova (member of the Public Chamber of the Russian Federation, retired judge)), YouTube, 16 September 2019] (Feb. 10, 2021), available at https://www.youtube.com/watch?v=CATQG8Wplk8. 
a serious obstacle to effective protection of victims from their abusers. However, it must also be noted that enforcement of such orders can be rather difficult even in countries where there is such a possibility. Police inertia and unprofessionalism, their dismissive and biased attitudes create a situation when abusers frequently go unpunished. ${ }^{61}$

The necessity of having a special law stems from deficiencies in legislation, and, from the point of view of many researchers, makes it difficult for the victims to have recourse to justice. One of the problems is the so-called private proceedings, ${ }^{62}$ when victims are supposed to collect evidence of crimes themselves, which often requires special skills which the victims lack. ${ }^{63}$ It can be difficult even for professionals, let alone for people who often endured years-long abuse and suffer from trauma.

Secondly, the de-criminalization of battery that took place in 2017 put cases of non-aggravated first-time instances of battery under administrative offenses. Federal Law No. 8-FZ "On Amendments to Article 116 of the Criminal Code of the Russian Federation" excluded the category of "close persons," making relatives and strangers equal before the law, leaving only racial, ethnic, social or disorderly motives. This has been seen as a dangerous step, also because the police do not see the need to intervene in family matters anymore, thus, a lot of cases remain unnoticed. ${ }^{64}$ In addition, when administrative fines are imposed on the abuser, they are often paid out of the family budget. ${ }^{65}$ The situation of helplessness and invisibility can be problematic from the point of view of growing homicide rates, when acting in selfdefense, victims exceed the acceptable boundaries and end up being convicted for murder under Article 105 of the Criminal Code. According to the study conducted by the United Nations in $2019,82 \%$ of women globally become victims of intimate partner homicide, compared to $18 \%$ of men. These figures for intimate partner/ family-related homicide represent $64 \%$ for women, and $36 \%$ of men. ${ }^{66}$

${ }_{61}$ Sandra S. Park, CEDAW's Promise for Strengthening Law-Enforcement Accountability to Survivors of Domestic and Sexual Violence in the United States, 2014 Mich. St. L. Rev. 357 (2014) (Feb. 12, 2021), also available at https://core.ac.uk/download/pdf/228470093.pdf.

62 Criminal Procedure Code of the Russian Federation, Arts. 20(2) \& 318.

63 "I Could Kill You and No One Would Stop Me": Weak State Response to Domestic Violence in Russia, Human Rights Watch, 25 October 2018 (Feb. 11, 2021), available at https://www.hrw.org/report/2018/10/25/icould-kill-you-and-no-one-would-stop-me/weak-state-response-domestic-violence.

64 Полиция не выносит ссоры из семьи // РБК. 25 ноября 2019 г. [The Police Keep Quarrels in the Family, RBC, 25 November 2019] (Feb. 10, 2021), available at https://www.rbc.ru/newspaper/2019/1 1/26/5dd7eeb19a79471ac83c65bc.

65 КрутихинаП. Декриминализация домашнего насилия: три года спустя // Закон. 2019. № 12. С. 112 119 [Polina Krutikhina, Decriminalization of Domestic Violence: Three Years After, 12 Law 112 (2019)] (Feb. 10, 2021), also available at https://igzakon.ru/magazine/article?id=8023.

66 The Global Study on Homicide, U.N. Office on Drugs and Crime (2019) (Feb. 10, 2021), available at https://www.unodc.org/unodc/en/data-and-analysis/global-study-on-homicide.html. 
Thirdly, a connected problem is that the state's protection measures can be applied only in situation when a criminal lawsuit begins, ${ }^{67}$ but they do not apply in relation to administrative offenses, thus victims of battery are not eligible to receive them.

May activists and researchers recognize, however, that adoption of a special law is not enough, there should be complex measures including training and education of law-enforcement officials, adequate counselling and service-provision to the victims, legal and psychological support to the family members. Complex and longterm measures are necessary to ensure protection of the victims. These measures should be accessible. ${ }^{68}$

And, more importantly, there must be recognition that the problem of domestic violence and violence against women is not a one-time occurrence that involves certain marginalized groups, it is a structural problem, facilitated by the culture of impunity and silence.

\section{COVID-19 and Domestic Violence}

The year 2020 brought about many challenges not envisaged before. Unprecedented measures like lockdowns, cordoning off cities, various forms of "selfisolation" regimes were introduced worldwide. In these conditions, human rights groups and international organizations started to emphasize how these measures adversely affected the most vulnerable members: children, elderly people, and often, women. In the conditions of quarantine, when it was impossible to obtain support from specialized organizations, friends or family members, many women and girls became vulnerable to abuse on the part of their husbands or intimate partners. ${ }^{69}$ On 6 April 2020, U.N. Secretary-General Antonio Guterres emphasized that, "horrifying global surge in domestic violence" was taking place, and that

healthcare providers and police are overwhelmed and understaffed ... local support groups are paralyzed or short of funds. Some domestic violence shelters are closed; others are full. ${ }^{70}$

67 Федеральный закон от 20 августа 2004 г. № 119-Ф3 «О государственной защите потерпевших, свидетелей и иных участников уголовного судопроизводства» // СПС «КонсультантПлюс» [Federal Law No. 119-FZ of 20 July 2004. On State Protection of Victims, Witnesses and Other Participants in Criminal Proceedings, SPS "ConsultantPlus"] (Feb. 10, 2021), available at http://www.consultant.ru/ document/cons_doc_LAW_48959/.

68 Давтян М. Законопроект о профилактике семейно-бытового насилия // Vmeste-RF. 3 декабря 2019 г. [Mary Davtian, Draft Law on the Prevention of Domestic Violence, Vmeste-RF, 3 December 2019], (Feb. 10, 2021), available at https://www.youtube.com/watch?v=iKjma2fg6bl.

69 "For many women and children, the home is not a safe place": Statement by the President of GREVIO, Marceline Naudi, on the need to uphold the standards of the Istanbul Convention in times of a pandemic, Council of Europe, 24 March 2020 (Feb. 10, 2021), available at https://rm.coe.int/greviostatement-covid-24-march-2020/pdfa/16809cf55e.

70 UN chief calls for domestic violence 'ceasefire' amid 'horrifying global surge,' U.N. News, 6 April 2020 (Feb. 10, 2021), available at https://news.un.org/en/story/2020/04/1061052. 
Soon after, other organizations continued in the same line by stressing women's vulnerability in the face of the crisis and appealed to their member states to offer special protection to victims. ${ }^{71}$

In late March - early April 2020 reports from various countries showed how complex the problem was. Notwithstanding the fact that victims were reluctant to report abuse (fearing retaliation if they attempted to call the police or other family members for help), figures still showed a dramatic increase in incidents of domestic violence: thus, Le Monde reported of the $30 \%$ increase in Paris and other French provinces, ${ }^{72}$ EU Observer gave even a higher a figure of $74 \%$ increase in requests for support at Italian anti-violence centers in the period of March 2 and April 5 compared to the monthly average in 2018, ${ }^{73}$ and The Guardian alarmingly stated that, "Domestic abuse killings'more than double."'74 Notorious murders were reported to have taken place (such as the murder of an Italian doctor Lorena Quaranta by her partner) ${ }_{1}^{75}$ and such dangerous behaviors as alcohol consumption and other forms of substance abuse continued to be on the rise. ${ }^{76}$

Various measures were reportedly taken by states to address this problem: for instance, in Belgium, hotels offered shelter to victims, ${ }^{77}$ in Germany women going to a pharmacy could use a special code-word so that the pharmacist would understand she was in trouble ${ }^{78}$ though those measures were considered inadequate with governments disoriented and unprepared ("Perfect storm"...). ${ }^{79}$

71 COVID-19 et violence à l'égard des femmes: Ce que le secteur et le système de santé peuvent faire, World Health Organization, 7 April 2020 (Feb. 10, 2021), available at https://apps.who.int/iris/bitstream/ handle/10665/331762/WHO-SRH-20.04-fre.pdf?sequence=1\&isAllowed=y.

72 Hausse des violences conjugales pendant le confinement, Le Monde, 30 March 2020 (Feb. 10, 2021), available at https://www.lemonde.fr/societe/article/2020/03/30/hausse-des-violences-conjugalespendant-le-confinement_6034897_3224.html.

73 Valentina Saini, Italy: After the balcony-singing stopped, EU Observer, 21 April 2020 (Feb. 10, 2021), available at https://euobserver.com/coronavirus/148116.

74 Jamie Grierson, Domestic abuse killings "more than double" amid Covid-19 lockdown, The Guardian, 15 April 2020 (Feb. 10, 2021), available at https://www.theguardian.com/society/2020/apr/15/domesticabuse-killings-more-than-double-amid-covid-19-lockdown.

75 Vincent Barone, Italian nurse strangles doctor girlfriend, claims she gave him coronavirus, New York Post, 1 April 2020 (Feb. 10, 2021), available at https://nypost.com/2020/04/01/italian-nurse-stranglesdoctor-girlfriend-claims-she-gave-him-coronavirus.

76 Brigid Delaney, Drinking in coronavirus isolation: experts warn Australians to monitor their intake, The Guardian, 6 April 2020 (Feb. 10, 2021), available at https://www.theguardian.com/lifeandstyle/2020/ apr/07/drinking-in-coronavirus-isolation-experts-warn-australians-to-monitor-their-intake.

77 Covid-19: à Bruxelles, un hôtel accueille les femmes victimes de violences conjugales, France24, 13 April 2020 (Feb. 10, 2021), available at https://www.france24.com/fr/video/20200413-covid-19\%C3\%A0-bruxelles-un-h\%C3\%B4tel-accueille-les-femmes-victimes-de-violences-conjugales.

78 Häusliche Gewalt: Geheimer Apotheken-Code hilft Frauen in Corona-Zeiten, Stern, 8 April 2020 (Feb. 10, 2021), available at https://www.stern.de/gesundheit/coronakrise--apotheken-helfen-beihaeuslicher-gewalt-mit-geheimen-code-9214306.html.

79 Perfect storm' for domestic violence during COVID-19, The Telegram, 17 April 2020 (Feb. 10, 2021), available at https://www.thetelegram.com/news/local/perfect-storm-for-domestic-violence-duringcovid-19-pandemic-wright-439148. 
Although the statistics in this field is uncertain (mostly it is collected by calculating women's calls to help lines), still the numbers are rather shocking: according to U.N. Women estimates, 243 million women and girls (age 15-49) became victims of sexual and/or physical violence by their intimate partner in the year 2020. ${ }^{80}$ The pandemic showed that women's rights work during crises and health emergencies should be completely re-formulated and re-oriented since traditional methods did not work anymore.

Reports of domestic violence increase during the pandemic started to circulate in Russia in the end of March-beginning of April, when the first social distancing measures were introduced in the country. Initially, the link between domestic violence and pandemic was voiced in Russia in connection with other countries like China which faced this calamity earlier and reported widespread nature of the abuse in the conditions of self-isolation..$^{81}$ During lockdown it was impossible to physically separate the victims from the abusers since movement around the cities was restricted, hostels were closed, and trains and buses were cancelled. At the same time, help centers working with the victims reported significant increase in the number of calls. ${ }^{82}$ While the Ministry of Interior reported of a decrease in domestic violence cases during lockdown ${ }^{83}$ Russia's Human Rights Commissioner, Tatiana Moskalkova, based on the reports by NGOs and the media, stated the opposite. She noted 2.5 times increase in numbers (from 6,054 in March 2020 to 13,000 in April 2020). ${ }^{84}$ Work on the draft law on domestic violence stopped during the pandemic. Valentina Matvienko, the speaker of Russia's Federation Council, mentioned that the work on the draft law would be resumed as soon as "the circumstances permit."1"

Some measures were taken by the government and by the private actors, however. For example, public services portal Gosuslugi posted information recommending

80 The Shadow Pandemic: Violence against women during COVID-19, U.N. Women (Feb. 10, 2021), available at https://www.unwomen.org/en/news/in-focus/in-focus-gender-equality-in-covid-19response/violence-against-women-during-covid-19.

81 Anna Andreeva et al., Women's Rights and the Feminists' "Dirty Plans": Media Discourses During the COVID-19 Pandemic in Russia, 36(3) Affilia 319 (2020), also available at https://journals.sagepub.com/ doi/full/10.1177/0886109920960826.

82 Domestic violence surge: Here's how Russia's authorities responded to rising domestic abuse during the coronavirus lockdown, Meduza, 17 July 2020 (Feb. 10, 2021), available at https://meduza.io/en/ feature/2020/07/17/domestic-violence-surge.

83 Domestic Violence in Russia:The Impact of the COVID-19 Pandemic, Chatham House, 20 July 2020 (Feb. 10, 2021), available at https://www.chathamhouse.org/2020/07/domestic-violence-russia-impactcovid-19-pandemic.

84 В России отмечен рост домашнего насилия с 10 апреля в 2,5 раза // РИА Новости. 5 мая 2020 г. [Domestic Violence Has Increased by 2.5 Times in Russia Since 10 April, RIA News, 5 May 2020] (Feb. 10, 2021), available at https://ria.ru/20200505/1570971794.html.

85 Russia Seeks Protections for Domestic Abuse Victims During Coronavirus Lockdown, The Moscow Times, 22 April 2020 (Feb. 10, 2021), available at https://www.themoscowtimes.com/2020/04/22/ russia-seeks-protections-for-domestic-abuse-victims-during-coronavirus-lockdown-a70071. 
victims what to do in cases of domestic violence, ${ }^{86}$ and police stations were required to provide information about social services. Some hotels allowed women to stay during lockdown. ${ }^{87}$ In general, however, these measures were reported to be inadequate and not always accessible. ${ }^{88}$ In addition, it was emphasized that the pandemic led to very serious social and economic problems, which had an enormous impact on women, especially, elderly women, single mothers, pregnant women, etc. ${ }^{89}$

During pandemic there has been growing interest to the problem of domestic violence not only among activists and policy-makers, but also among researchers. If publications related to this topic in Russia were rather scarce, in 2020 the number of such publications significantly increased. Researchers sought to examine legal, societal, criminological and other related aspects of domestic violence and violence against women, including psychological violence, domestic violence against minority women, etc. They looked into not just legal and procedural aspects, but also the case-law of Russian courts to point out what problems existed when the courts examined such crimes. For example, how difficult it could be to establish the gravity of battery since often battery could be serious but left no visible marks. ${ }^{90}$ Judges' biased attitudes towards the victims (who were often blamed for what happened because they, for example, should have tried to run away from the abuser) were also mentioned. ${ }^{91}$ And even if the authors were not always sure why the special law was necessary and what form it should eventually take, they all recognized that the problem existed and must be addressed.

86 Меры для предупреждения кризисной ситуации // Госуслуги [Crisis Prevention Measures, Gosuslugi] (Feb. 10, 2021), available at https://www.gosuslugi.ru/domestic_abuse; Куда обратиться пострадавшим от домашнего насилия во время самоизоляции // Госуслуги [Who Should Domestic Violence Victims Contact During Self-Isolation, Gosuslugi] (Feb. 10, 2021), available at https://gu.spb. ru/news/kuda-obratitsya-postradavshim-ot-domashnego-nasili/.

Russia: Surge in violence against women, DW, 4 July 2020 (Feb. 10, 2021), available at https://www. dw.com/en/russia-surge-in-violence-against-women/av-53923220.

88 Svetlana Gromova \& Olga Karacheva, Domestic violence in the age of COVID-19 in Russia, Submission on behalf of seven women's rights organisations: "Zona Prava," ANNA - Centre for the Prevention of Violence, Consortium of Women's Non-Governmental Associations, Russian Justice Initiative (RJ), "YouAreNotAlone" Women's Mutual Help Network, The Sisters Centre, The Kitezh Centre (Feb. 10, 2021), available at https://srji.org/upload/medialibrary/fd8/GBV_in_RUSSIA_COVID_19.pdf. Larisa Zhukova, How COVID-19 pandemic affected women in Russia, Heinrich Böll Foundation, 19 June 2020 (Feb. 10, 2021), available at https://eu.boell.org/en/2020/06/18/how-covid-19-pandemic-affectedwomen-russia.

Химиченко В. Побои в семье - анализ споров // Журнал российского права. 2020. № 1; Административное право. 2020. № 2 // СПС «КонсультантПлюс» [V. Khimichenko, Family Battery: Analysis of Case-Law, 1 Journal of Russian Law, 2 Administrative Law (2020), SPS "ConsultantPlus"].

91 Грязнова Д. Право жертв домашнего насилия на необходимую оборону: стереотипы и предрассудки в решениях российских судов // Зона Права. 6 ноября 2020 г. [Dariana Gryaznova, The Right of Domestic Violence Victims to the Necessary Defense: Stereotypes and Prejudices in Russian Courts' Decisions, Zona Prava, 6 November 2020] (Feb. 10, 2021), available at https://zonaprava.com/ events/doklad-zony-prava-rossiyskie-sudi-stereotipno-podkhodyat-k-delam-o-samooborone-pridomashnem-nasilii/. 
Brazil faced very similar challenges as Russia did. First of all, one of the problems was that the number of services offered to women significantly reduced. According to the data gathered by the Brazilian Public Security Forum,

the number of emergency protective measures granted in São Paulo had dropped 38 percent during the first two weeks of April compared to the same period last year, even as domestic violence calls to the state's emergency 190 hotline rose 45 percent. $^{92}$

In addition,

In some states, such as Rio de Janeiro, São Paulo, and the Federal District, police stations are still open 24 hours a day. But elsewhere, police stations, including special precincts for women created by the landmark 2006 Maria da Penha law, are operating under reduced hours. São Paulo and Rio de Janeiro are allowing virtual domestic violence complaints, and São Paulo is allowing judges to grant emergency protective measures virtually, and transmitting summonses through WhatsApp. ${ }^{93}$

According to the World Bank estimates, the number of calls women made to the help lines in the period of March-April 2020 in Brazil increased by 27\% compared to the same period a year ago. ${ }^{94} \mathrm{At}$ the same time, police reports on violence against women decreased, ${ }^{95}$ which, however, did not mean the number of crimes went down, but that women might have had difficulties contacting the police.

Alcohol and drug use, stress, anxiety, and boredom during confinement increased the likelihood of aggressive behavior, especially among people with dysfunctional personality traits or personality disorders and brought about the need to involve mental health professionals to address domestic violence cases. ${ }^{96}$

92 Anya Prusa et al., Pandemic of Violence: Protecting Women During COVID-19, Wilson Center, 15 May 2020 (Feb. 10, 2021), available at https://www.wilsoncenter.org/blog-post/pandemic-violence-protectingwomen-during-covid-19.

93 Id.

94 O Combate à Violência contra a Mulher (VCM) no Brasil em época de COVID-19, World Bank, 25 June 2020 (Feb. 10, 2021), available at http://documents1.worldbank.org/curated/en/807641597919037665/ pdf/Addressing-Violence-against-Women-VAW-under-COVID-19-in-Brazil.pdf.

95 Violência doméstica durante a pandemia de Covid-19, Fórum Brasileiro de Segurança Pública, 24 July 2020 (Feb. 10, 2021), available at https://forumseguranca.org.br/wp-content/uploads/2018/05/ violencia-domestica-covid-19-ed03-v2.pdf.

96 Lisieux E. de Borba Telles et al., Domestic Violence in the COVID-19 Pandemic: A Forensic Psychiatric Perspective, 43(3) Braz. J. Psychiat. 233 (2020) (Feb. 10, 2021), also available at https://www.scielo.br/ $\mathrm{pdf} / \mathrm{rbp} / 2020$ nahead/1516-4446-rbp-1516444620201060.pdf. 
Government and civil-society led responses to domestic violence and violence against women in Brazil included awareness campaigns, dissemination of information, online platforms and apps for reporting the cases (that would allow uploading photos and videos), etc. A special Decree (Decree No. 10.282) was adopted that prescribed provision of essential services to the most vulnerable people during quarantine. ${ }^{97}$

\section{Conclusion}

One of the important contributions of international and regional human rights institutions in the field of women's rights protection has been the blurring of the public/private debate that obscured and downplayed women's experience as victims of violence. The U.N. bodies, as well as regional courts, have shown that they are important actors in a global debate on women's rights and have an impact on domestic developments. It must be noted that in international and regional human rights bodies there is some progress regarding the recognition of many contexts and experiences of women who suffer from violence and other social harms.

The need to address the question of intersectionality at both international and domestic levels remains an important issue, however. It has to be seen how these international and regional institutions will be able to respond to such complex issues as violence against women under health emergencies, since pandemic 2020 clearly demonstrated that it is impossible to separate questions of domestic violence from women's social and economic rights that include not only women's financial autonomy but also such issues as access to healthcare, psychological and legal counselling, and social benefits. It has been emphasized by researchers that focus on bodily harm obscures (and even excludes) other aspects of harm women might experience as a result of structural inequalities, ${ }^{98}$ thus, examination of wider contexts of harm, including social harm, is very important. It has been recognized that "violence toward women and children increases with alcohol and drug use, mental health issues, and inadequate housing," and can be exacerbated by periods of crisis, thus, it is impossible to address this problem in a vacuum. ${ }^{99}$

Disconnection from institutional, medical, and informal support networks makes domestic violence, more than ever, isolating and life-threatening. (...)

97 Gabriela Bastos et al., Addressing Violence Against Women (VAW) Under COVID-19 in Brazil, World Bank Group, 25 June 2020 (Feb. 10, 2021), available at https://reliefweb.int/sites/reliefweb.int/files/ resources/Addressing-Violence-against-Women-VAW-under-COVID-19-in-Brazil.pdf.

98

Diana Sankey, Recognition of Gendered Experiences of Harm at the Extraordinary Chambers in the Courts of Cambodia: The Promise and the Pitfalls, 24(1) Fem. Leg. Stud. 7 (2016).

99 Jean-Baptiste Bouillon-Minois et al., Coronavirus and Quarantine: Catalysts of Domestic Violence, Violence Against Women (2020), at 1-3 (Feb. 11, 2021), available at https://journals.sagepub.com/ doi/full/10.1177/1077801220935194. 
For many women and children, being quarantined with a violent partner and parent is as dangerous - and for some, more dangerous - than the pandemic. ${ }^{100}$

It is recognized that there is a link between poverty and infectious disease, which can be exacerbated by power disbalances in relations between men and women, and the lack of trust in public institutions. ${ }^{101}$ As Russia's case shows, the lack of a special law to protect victims exacerbated an already difficult situation when victims and abusers were forced to self-isolate, and the problem of substance abuse, physical, sexual and verbal violence was noted by the media more and more often. In Brazil, despite the fact that legislative framework was in place, it was still difficult to ensure consistent protection of women, especially women belonging to minorities, refugee women, etc. ${ }^{102}$ Thus, it appears imperative that women take an active part in decisionmaking at the national and local level in times of crisis as well, especially women directly involved in healthcare, service-provision, humanitarian work, etc.

However, given that this problem is not country-specific, the necessity and urgency of strengthened international instruments to combat domestic violence is apparent. It is our hope that in the post-pandemic scenarios states will recognize the need to introduce legislative and other measures to combat this problem not only domestically, but also on the global scale.

Finally, it must be stressed that the states should also deliberate the adoption of an additional protocol to the CEDAW Convention, or a separate convention, that would regulate such questions as violence against women perpetrated online. Pandemic 2020 showed how technologies can be an indispensable part of people's lives, which, however, has multiple negative side effects, including emotional burnout, social media addition, fatigue, and depression. ${ }^{103}$ The problem of cyber violence and cyber bullying, especially among schoolchildren and teenagers, has not yet been addressed in international treaties, even though international organizations and NGOs have issued numerous appeals to the states urging them to penalize cyber violence in their criminal law, stating that this kind of violence

100 Bouillon-Minois et al., supra note 99 , at 3.

101 Marlene Laruelle et al., Pandemic Politics in Eurasia: Roadmap for a New Research Subfield, 68(1) Probl. Post-Communism 1 (2020) (Fen. 10, 2021), also available at https://www.tandfonline.com/doi/full/ $10.1080 / 10758216.2020 .1812404$.

Gender and COVID-19 in Latin America and the Caribbean Integrating Gender into the Preparedness and Response Frameworks, U.N. Women Regional Office for the Americas and the Caribbean (2020) (Feb. 10, 2021), available at https://www.onumulheres.org.br/wp-content/uploads/2020/03/ enbriefing-coronavirusv1117032020.pdf.

103 Dana R. Garfin, Technology as a Coping Tool During the Coronavirus Disease 2019 (COVID-19) Pandemic: Implications and Recommendations, 36(4) Stress Health 555 (2020) (Feb. 11, 2021), also available at https://pubmed.ncbi.nlm.nih.gov/32762116/. 
can take many forms, including (sexual) harassment, revenge porn and threats of rape, sexual assault or murder. Perpetrators can be partners or ex-partners, colleagues, schoolmates or, as is often the case, anonymous individuals. ${ }^{104}$

\section{References}

Andreeva A. et al. Women's Rights and the Feminists' "Dirty Plans": Media Discourses During the COVID-19 Pandemic in Russia, 36(3) Affilia 319 (2020). https://doi.org/10. 1177/0886109920960826

Barnett O.W. et al. Family Violence Across the Lifespan: An Introduction ( $3^{\text {rd }}$ ed. 2010).

Bouillon-Minois J.-B. et al. Coronavirus and Quarantine: Catalysts of Domestic Violence, Violence Against Women (2020). https://doi.org/10.1177/1077801220935194

Brandão E.R. \& Cabral C.S. Sexual and Reproductive Rights Under Attack: The Advance of Political and Moral Conservatism in Brazil, 27(2) Sex. Reprod. Health Matters 76 (2019). https://doi.org/10.1080/26410397.2019.1669338

Campbell M. CEDAW and Women's Intersecting Identities: A Pioneering New Approach to Intersectional Discrimination, 11(2) Revista Direito GV 479 (2015).

De Vido S. The Ratification of the Council of Europe Istanbul Convention by the EU: A Step Forward in the Protection of Women from Violence in the European System, 9(2) Eur. J. Leg. Stud. 69 (2017).

Garfin D.R. Technology as a Coping Tool During the Coronavirus Disease 2019 (COVID19) Pandemic: Implications and Recommendations, 36(4) Stress Health 555 (2020). https://doi.org/10.1002/smi.2975

Hasselbacher L. State Obligations Regarding Domestic Violence: The European Court of Human Rights, Due Diligence, and International Legal Minimums of Protection, 8(2) Nw. J. Int'I Hum. Rts. 190 (2010).

Hodson L. Women's Rights and the Periphery: CEDAW's Optional Protocol, 25(2) Eur. J. Int'I L. 561 (2014). https://doi.org/10.1093/ejil/chu027

Klimek L. Domestic Violence in European Legal Documents, 6(0) CBU Int'I Conf. Proc. 647 (2018). https://doi.org/10.12955/cbup.v6.1227

Laruelle M. et al. Pandemic Politics in Eurasia: Roadmap for a New Research Subfield, 68(1) Probl. Post-Communism 1 (2020).

Marino K.M. Feminism for the Americas: The Making of the International Human Rights Movement (2019).

104 Stop cyberviolence against women and girls, Statement, Council of Europe Commissioner for Human Rights, 25 November 2011 (Feb. 10, 2021), available at https://www.coe.int/en/web/commissioner/-/ stop-cyberviolence-against-women-and-girls; Cyber violence against women and girls, Report, European Institute for Gender Equality, 23 June 2017 (Feb. 10, 2021), available at https://eige.europa. eu/publications/cyber-violence-against-women-and-girls; Eliminating Online Violence Against Women and Engendering Digital Equality, Submission by the Due Diligence Project to the Office of the High Commissioner for Human Rights Pursuant to Human Rights Council Resolution 32/13 on Ways to Bridge the Gender Digital Divide from a Human Rights Perspective (2015) (Feb. 10, 2021), available at https://www.ohchr.org/Documents/Issues/Women/WRGS/GenderDigital/DueDiligenceProject.pdf. 
Martins Amaral A.P. \& Rocha Amorim E.C. A Lei 11.340/2006 - Lei Maria da Penha como fruto dos compromissos internacionais assumidos pelo Brasil e de sua condenação perante a Comissão Interamericana de Direitos Humanos, 29(2) Revista Justiça do Direito 179 (2015). https://doi.org/10.5335/rjd.v29i2.5586

Moore C. Women and Domestic Violence: The Public/Private Dichotomy in International Law, 7(4) Int'l J. Hum. Rts. 93 (2010). https://doi.org/10.1080/1364298031 0001726236

Park S.S. CEDAW's Promise for Strengthening Law-Enforcement Accountability to Survivors of Domestic and Sexual Violence in the United States, 2014 Mich. St. L. Rev. 357 (2014).

Prandini Assis M. Violence Against Women as a Translocal Category in the Jurisprudence of the Inter-American Court of Human Rights, 8(2) Revista Direito e Práxis 1507 (2017). https://doi.org/10.12957/dep.2017.28032

Roure J.G. Domestic Violence in Brazil: Examining Obstacles and Approaches to Promote Legislative Reform, 41(1) Colum. Hum. Rts. L. Rev. 67 (2009).

Salomón M. Exploring Brazilian Foreign Policy Towards Women: Dimensions, Outcomes, Actors and Influences, 63(1) Revista Brasileira de Política Internacional 1 (2020). https://doi.org/10.1590/0034-7329202000101

Smith R.K.M. Texts and Materials on International Human Rights ( $3^{\text {rd }}$ ed. 2013). https://doi.org/10.4324/9780203410059

Spieler P. The Maria da Penha Case and the Inter-American Commission on Human Rights: Contributions to the Debate on Domestic Violence Against Women in Brazil, 18(1) Indiana J. Glob. Leg. Stud. 121 (2011). https://doi.org/10.2979/indjglolegstu.18.1.121

Stoeckl K. \& Medvedeva K. Double Bind at the UN: Western Actors, Russia, and the Traditionalist Agenda, 7(3) Glob. Const. 383 (2018). https://doi.org/10.1017/s204538 1718000163

Telles L. et al. Domestic Violence in the COVID-19 Pandemic: A Forensic Psychiatric Perspective, 43(3) Braz. J. Psychiat. 233 (2020). https://doi.org/10.1590/1516-44462020-1060

\section{Information about the author}

Galina Nelaeva (Tyumen, Russia) - Professor, Department of Modern History and World Politics, Institute of Social Sciences and Humanities, Tyumen State University (38 Lenina St., Tyumen, 625000, Russia; e-mail: gnelaeva@mail.ru). 